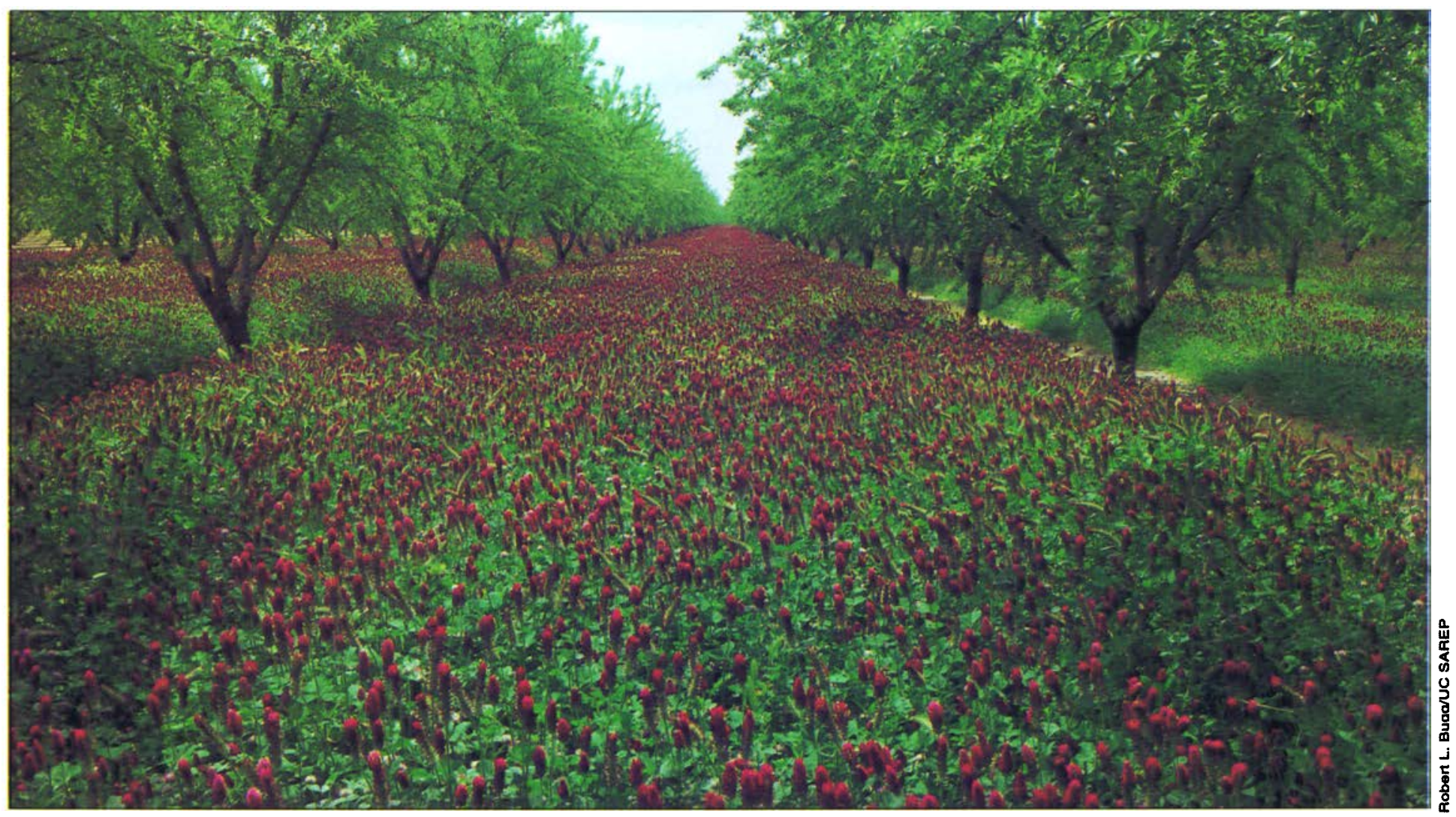

Cover crops, such as the clover on the floor of this almond orchard, are an integral component of biologically integrated orchard system (BIOS) projects.

\title{
Growth predicted in biologically integrated and organic farming
}

\author{
Sean L. Swezey a Janet C. Broome
}

California agriculture faces multiple environmental challenges, the result of a fast-growing population, the increased role of consumers in decision-making about the food system, a more restrictive regulatory climate and mounting evidence of agriculture's contribution to nonpoint-source water pollution. At the same time, innovative partnerships involving growers, consumers, commodity boards, regulators and university researchers are exploring creative solutions to these challenges through biologically integrated and organic farming systems. Simultaneously, the agricultural biotechnology industry is experiencing phenomenal growth. The U.S. food industry's resistance to labeling products that contain transgenic ingredients is stimulating consumer interest in organic products, which prohibit transgenics. Based on these trends and the growth of organic acreage and product sales, we predict that alternative farming systems could comprise at least $20 \%$ and as much as $60 \%$ of all California cropland in production in 2025. Nonetheless, research investments into alternative biologically integrated and organic methods lags far behind organic product sales. alifornia simultaneously leads the nation in agricultural production, biodiversity, listed endangered species, yearly urban population growth and immigration. From stratosphere to coastal estuary waters, from farm field to dinner table, California's food and fiber production systems function on a highly visible environmental stage. Over the next 25 years, California's system of agricultural production will be scrutinized ever more closely for its social and environmental impacts.

Renowned as a diversified, $\$ 28$ billion enterprise, California agriculture is expected to continue its national prominence in the production of forage, livestock products, grapes, tree fruits and nuts, strawberries and vegetables over the next quarter-century. 
But evidence is also mounting that a radically altered social and environmental landscape will confront California agriculture in the new century.

Population growth. California's population has nearly doubled in 30 years to 35 million residents, and is projected to reach 52 million by 2030 (Clark 2000). This growth could directly reduce California's farmland base in the Central Valley alone by an estimated 1 million acres (Bradshaw and Muller 1998). Much of the urban conversion will be on some of the state's richest agricultural soils.

California's population growth has resulted in more contact and more conflict between farms and sprawling cities and suburbs. Production agriculture has entered a volatile political struggle over land, air, water and other resources (Medvitz and Sokolow 1995).

Consumer activism. Motivated global consumers and environmentalists are demanding more active participation in shaping the quality and sustainability of California's farm and food systems (The Hartman Group 1996). Increasing numbers of consumers and public-interest groups are calling for disclosures on food labels regarding genetically modified organisms, countries of origin and even the labor practices employed in food production (Barham 1997).

Environmental regulation. California farmers and ranchers face increasing restriction, regulation and outright prohibition of farming practices considered commonplace until recently. These changes will have a lasting impact on California agriculture.

The 1996 Food Quality Protection Act requires the U.S. Environmental Protection Agency (U.S. EPA) to review some 9,000 pesticide tolerances, including the widely used organophosphate and carbamate insecticides. Agricultural uses of several insecticides including chlorpyrifos, methyl parathion and azinphos methyl have already been scaled back. At the same time, the U.S. Clean Air Act and the United Nations Montreal Protocol, an international treaty concerning ozone depletion, will require the United

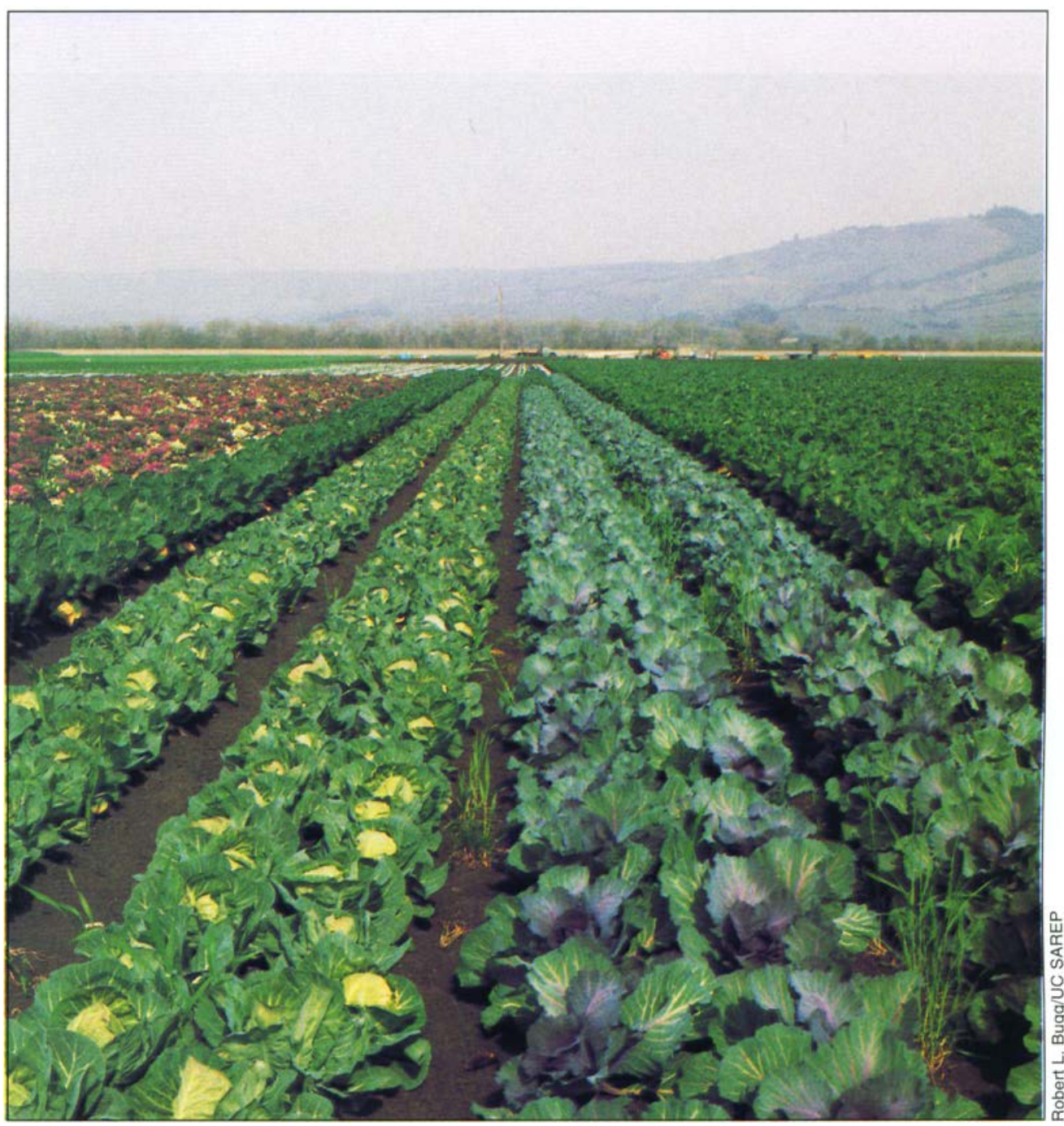

By 2025 , from $20 \%$ to $60 \%$ of California crop acreage could be in alternative farming systems, including organic farms such as this one in Watsonvilie.

States and most developed countries to stop using the popular fumigant methyl bromide by 2005. The 1994 CALFED agreement provides ecosystem protection for the San Francisco Bay-Delta Estuary while giving agricultural water users a guaranteed, if reduced, water supply (CALFED 1999).

Water quality. Environmental monitoring and analysis has determined that agriculture remains a leading factor in non-point-source pollution in California waterways (SWRCB 1999). For example, insecticides applied during dormant orchard season threaten surface-water quality in the Central Valley. From 1992 to 1995, U.S. Geological Survey (USGS) researchers routinely detected diazinon and other insecticides in excess of water-quality criteria in the San Joaquin River and its tributaries (Dubrovsky et al. 1998).

\section{GLOSSARY OF ACRONYMS}

BIFS Biologically Integrated Farming Systems

BIOS Biologically Integrated Orchard Systems

CAFF Community Alliance with Family Farmers

DPR California Department of Pesticide Regulation

IPFP Integrated Prune Farming Practices

LWWC Lodi-Woodbridge Winegrape Commission

NRCS Natural Resources Conservation Service

PCAs Pest Control Advisers

SAREP Sustainable Agriculture Research and Education Program

USDA U.S. Department of Agriculture

U.S. EPA U.S. Environmental Protection Agency 


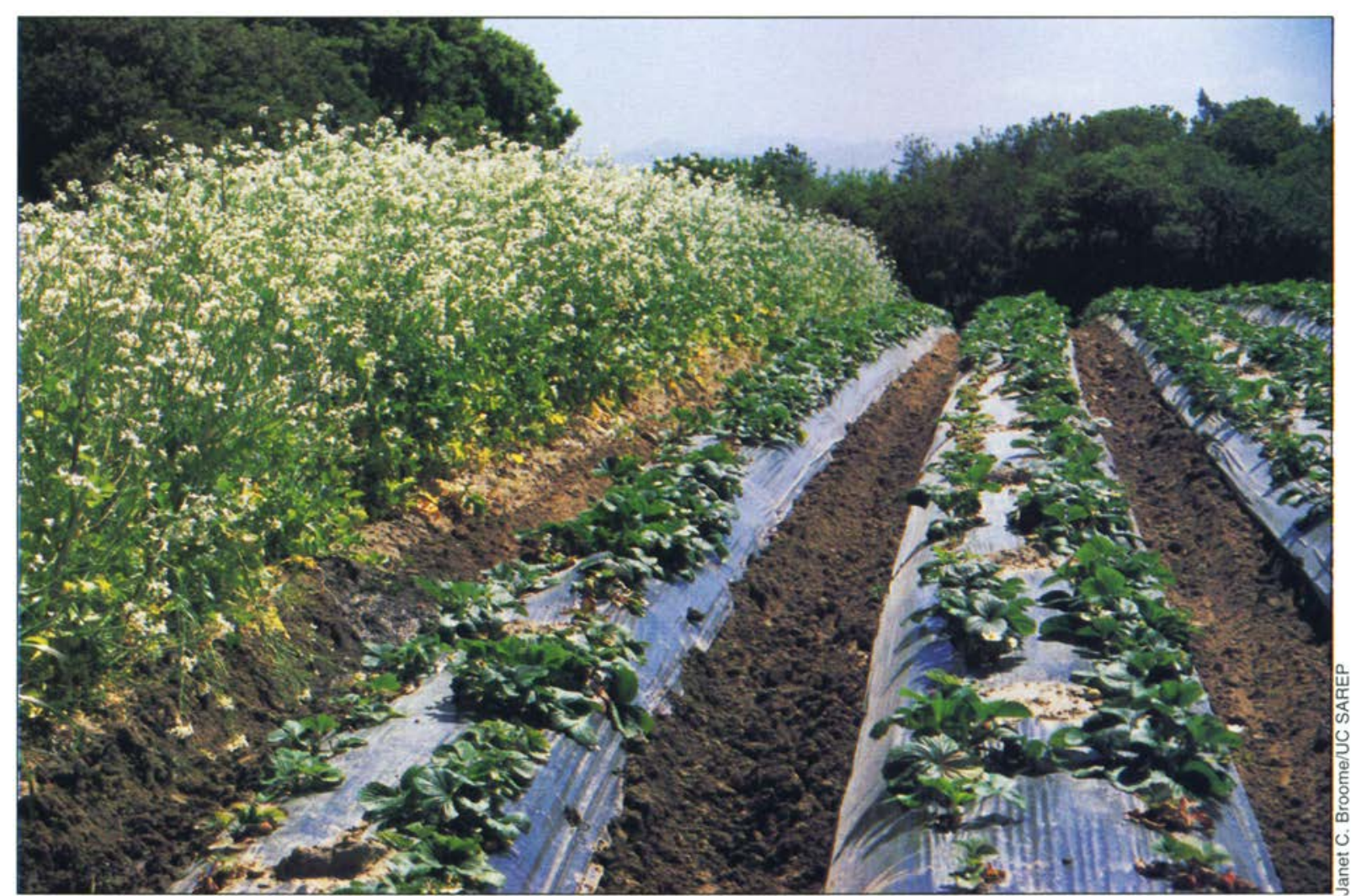

With the scheduled phase-out of methyl bromide by 2005, strawberry growers are looking for alternative pest- and disease-control methods. Beneficial insects, "farmscaping" and nonchemical weed control are components of the Biological Agriculture Systems in Strawberries (BASIS) project, in Monterey and Santa Cruz counties.

In this new revolution, shared knowledge of biological processes that determine pest dynamics, soil bealth and microbial ecology will combine with the demonstrated ability of Califormia growers and agricultural researchers to innovate, thereby maintaining the preeminence of California commodities.
Monitoring has also revealed soilabsorbed organochlorines from historical pest-management practices (Klienfelder Inc. 1993) and organophosphate insecticide residues some above toxicity thresholds for resident aquatic species - in wetlands and waterways that drain into the Monterey Bay National Marine Sanctuary, the nation's largest of its kind (Hunt et al. 1999).

Likewise, herbicides and nitrates from crop and animal production threaten California's groundwater quality. Herbicides such as simazine are the most commonly detected pesticides in annual state surveys of domestic wells (DPR 1996). In a recent USGS study, simazine was detected in $50 \%$ of California groundwater samples (Burow et al. 1998). On the Central Coast, highly soluble nitrates from agricultural fertilizers applied in the Pajaro Valley have contaminated drinking-water wells, with nitrate levels exceeding maximum allowable contamination levels for potable uses (Montgomery Watson Consultants 1993). Most recently, groundwater contamination has been associated with some California dairy operations due to liquid waste management and forage-crop production practices (Morse et al. 1997).

\section{Agricultural} biotechnology. Conflicts over the role of agricultural biotechnology are certain to continue well into the 21st century. In 1999, more than half of 72 million acres of U.S. soybeans were genetically engineered with resistance to the herbicide glyphosate ("Roundup Ready") (Abelson and Hines 1999). However, in response to consumer concerns about transgenic food - mostly in Europe and Japan - Archer Daniels Midland, the nation's largest soybean purveyor, announced in 1999 that it would segregate engineered soybeans and offer price premiums to growers with nongenetically modified crops. Gerber recently announced it would not use genetically engineered ingredients in baby foods, while Frito-Lay and other major food processors announced plans to exclude transgenic ingredients from some of their products.

\section{Resolving conflict by partnering}

California agriculture can survive regulatory and other pressures by forging partnerships among growers, consumers, commodity boards, regulators and university researchers.

These new partnerships can be seen as an expansion of past farm input and grower marketing cooperatives as well as farm lobby organizations. By bringing together diverse food-system par- 
ticipants, partnerships help growers to adopt forwardlooking approaches to contemporary pressures rather than waiting for change to be imposed by regulatory agencies. Model partnerships rely heavily on information-sharing to make the kinds of environmentally sound changes that consumers want.

Of central importance, farmers and ranchers are partnering with research and agricultural professionals to maximize the use of biologically derived sources of pest control and soil fertility to reduce their reliance on agricultural chemicals. The first such voluntary partnership in California, known as BIOS (Biologically Integrated Orchard Systems), was formed in 1993 and is administered by the nonprofit Community Alliance with Family Farmers (CAFF).

Following early BIOS successes, the state legislature created a competitive grants program called Biologically Integrated Farming Systems (BIFS) in 1995. BIFS seeks to reduce reliance on targeted chemicals, maintain farm productivity and protect natural resources and wildlife. To date, about a dozen BIFS and BIOS demonstration projects have received just over $\$ 4$ million in funding from federal and state agencies, including the U.S. EPA, CALFED, the California Department of Pesticide Regulation and an array of foundations. The UC Sustainable Agriculture Research and Education Program (SAREP) administers the BIFS program.

Since 1993, nearly 240 growers farming 200,000 total acres have participated in on-farm BIOS and BIFS projects, with about $26,866.5$ demonstration acres (table 1).

\section{BIFS/whole-systems approach}

The BIFS program exemplifies a biological or "whole-farming-system" approach to agricultural extension and non-point-source pollution prevention. In contrast to a traditional regula-

tory approach that prescribes singlepurpose "best management practices," the farming-systems approach addresses multiple environmental impacts by managing the farm as an interactive biological system.

Comprehensive management considers the inherent links among the components of a farming system (tillage practices, crop rotation, nutrients, water and pest management) and the larger landscape and watershed. Emphasis on one objective to the exclusion of others can cause unnecessary environmental trade-offs and increase costs, slow the rate of adoption and decrease the effectiveness of new technologies and management methods (NRC 1993).

BIFS growers work with biological sources of pest control and soil fertility to the greatest extent possible. For example, cover crops are used to supply nitrogen, improve orchard and field access in wet months, suppress weeds, provide habitat for beneficial arthropods, manage plant vigor and increase infiltration rates (Ingels et al. 1998; Prichard et al. 1989;

Folorunso et al. 1992).

On a typical BIFS demonstration project, each grower enrolls 10 to 20
At a BIOS field day, growers, advisors, regulators and others gather to share information. Partnerships help growers to voluntarily adopt forward-looking, environmentally sound practices.

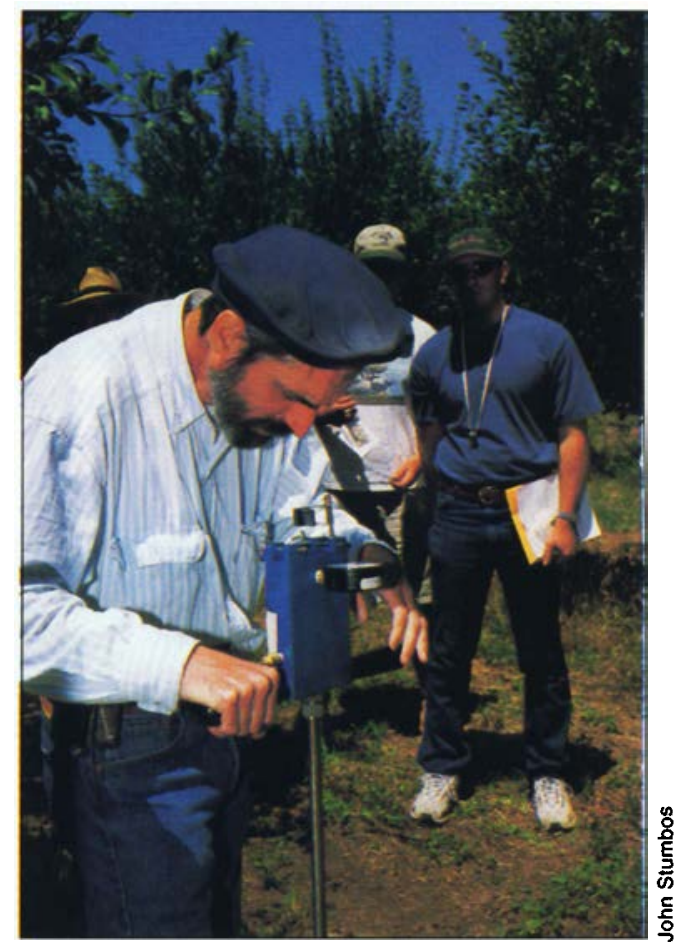

UC pomologist Ken Shackel demonstrates the "pressure bomb" during an integrated Prune Farming Practices program training day. The machine uses air pressure to measure water levels in plant leaves, allowing for more precise irrigation. 
TABLE 1. Biologically Integrated Farming Systems (BIFS) projects, January 2000

\begin{tabular}{|c|c|c|c|c|c|c|c|c|c|c|}
\hline $\begin{array}{l}\text { Year } \\
\text { begun }\end{array}$ & Project & Counties & $\begin{array}{l}\text { Farmers } \\
\text { enrolled }\end{array}$ & $\begin{array}{l}\text { Demon- } \\
\text { stration } \\
\text { acres }\end{array}$ & $\begin{array}{l}\text { Acres } \\
\text { farmed } \\
\text { by BIFS } \\
\text { growers }\end{array}$ & $\begin{array}{l}\text { Total } \\
\text { bearing } \\
\text { acres } \\
\text { in state } \\
(1998)^{*}\end{array}$ & $\begin{array}{l}\text { Acreage } \\
\text { served } \\
\text { by BIFS } †\end{array}$ & $\begin{array}{l}\text { Demonstrated } \\
\text { practices } \\
\text { of farming } \\
\text { system }\end{array}$ & $\begin{array}{l}\text { Inputs } \\
\text { targeted } \\
\text { for risk/use } \\
\text { reduction }\end{array}$ & $\begin{array}{c}\text { Resource } \\
\text { and wildlife } \\
\text { conservation } \\
\text { practices }\end{array}$ \\
\hline & & \multicolumn{9}{|c|}{$\%$} \\
\hline $1993 \ddagger$ & $\begin{array}{l}\text { BIOS } \\
\text { for } \\
\text { almonds }\end{array}$ & $\begin{array}{c}\text { Merced } \\
\text { Stanislaus } \\
\text { Madera } \\
\text { San Joaquin } \\
\text { Colusa }\end{array}$ & 87 & 19,277 & 33,820 & 460,000 & 7.4 & $\begin{array}{c}\text { Bt at bloom, } \\
\text { cover crops, } \\
\text { monitoring \& } \\
\text { action thresholds, } \\
\text { enhance \& release } \\
\text { beneficial species }\end{array}$ & $\begin{array}{c}\text { Dormant \& } \\
\text { in-season } \\
\text { organophosphate } \\
\text { insecticides, } \\
\text { pre-emergence } \\
\text { herbicides, } \\
\text { synthetic N }\end{array}$ & $\begin{array}{l}\text { Cover crops, } \\
\text { insectary } \\
\text { plants }\end{array}$ \\
\hline $1994 \ddagger$ & $\begin{array}{l}\text { BIOS } \\
\text { for } \\
\text { walnuts }\end{array}$ & $\begin{array}{c}\text { Yolo } \\
\text { Solano } \\
\\
\text { San Joaquin } \\
\text { Stanislaus }\end{array}$ & 20 & ${ }^{230}$ Tot & $\begin{array}{c}2,530 \\
\operatorname{tal}=3,430\end{array}$ & 193,000 & 1.8 & $\begin{array}{c}\text { Cover crops, } \\
\text { mating disruption, } \\
\text { enhance } \\
\text { beneficial species, } \\
\text { monitoring, action } \\
\text { threshoids, compost }\end{array}$ & $\begin{array}{c}\text { In-season } \\
\text { insecticides } \\
\& \text { acaricides, } \\
\text { pre-emergence } \\
\text { herbicides, } \\
\text { synthetic } N\end{array}$ & $\begin{array}{l}\text { Cover crops, } \\
\text { insectary } \\
\text { shrubs, } \\
\text { tailwater ponds } \\
\text { riparian } \\
\text { restoration }\end{array}$ \\
\hline $1995 \S$ & $\begin{array}{l}\text { BIFS for } \\
\text { Winegrapes/ } \\
\text { Lodi- } \\
\text { Woodbridge } \\
\text { Winegrape } \\
\text { District }\end{array}$ & $\begin{array}{l}\text { San Joaquin } \\
\text { Sacramento }\end{array}$ & $\begin{array}{r}43(+16 \\
\text { PCAs) }\end{array}$ & 2,370 & 30,000 & 385,000 & 7.8 & $\begin{array}{l}\text { Cover crops, } \\
\text { beneficial species, } \\
\text { monitoring, } \\
\text { action thresholds, } \\
\text { disease risk models, } \\
\text { canopy management }\end{array}$ & $\begin{array}{l}\text { Pre-emergence } \\
\text { herbicides, } \\
\text { synthetic N, } \\
\text { organophosphate } \\
\text { insecticides, } \\
\text { fungicides }\end{array}$ & $\begin{array}{l}\text { Cover crops, } \\
\text { shelters/ } \\
\text { perches } \\
\text { for raptors, } \\
\text { riparian } \\
\text { restoration }\end{array}$ \\
\hline $1995 \S$ & $\begin{array}{l}\text { Extending } \\
\text { Biologically } \\
\text { Integrated } \\
\text { Farming/ } \\
\text { West Side } \\
\text { San Joaquin } \\
\text { Valley }\end{array}$ & Fresno & 12 & 1,653 & 90,000 & 846,150 & 10.6 & $\begin{array}{l}\text { Compost, cover } \\
\text { crops, soil \& } \\
\text { plant fertility } \\
\text { testing. } \\
\text { crop rotation, } \\
\text { time of planting, } \\
\text { action thresholds }\end{array}$ & $\begin{array}{l}\text { Synthetic } \\
\text { nitrogen } \\
\text { fertilizers, } \\
\text { herbicides, } \\
\text { insecticides }\end{array}$ & $\begin{array}{l}\text { Cover crops, } \\
\text { cow pea } \\
\text { border strips } \\
\text { for trap } \\
\text { cropping }\end{array}$ \\
\hline $1999 \ddagger$ & $\begin{array}{l}\text { Integrated } \\
\text { Prune } \\
\text { Farming } \\
\text { Practices } \\
\text { (IPFP) }\end{array}$ & $\begin{array}{c}\text { Butte, Fresno } \\
\text { Glenn } \\
\text { Madera } \\
\text { Merced } \\
\text { Sutter } \\
\text { Tehama } \\
\text { Tulare } \\
\text { Yolo, Yuba }\end{array}$ & 22 & 708 & 6,303 & 83,000 & 7.6 & $\begin{array}{l}\text { Monitoring } \\
\text { for insects etc., } \\
\text { water use \& } \\
\text { quality monitoring, } \\
\text { Bt \& less toxic } \\
\text { insecticides, } \\
\mathrm{N} \text { and } \mathrm{K} \text { monitoring, } \\
\text { cover crops, compost }\end{array}$ & $\begin{array}{l}\text { Organophosphate } \\
\text { insecticides } \\
\text { in dormant } \\
\text { applications } \\
\text { (90\% reduction } \\
\text { in } 5 \text { years), } \\
\text { synthetic N } \\
\text { fertilizer }\end{array}$ & $\begin{array}{l}\text { Cover crops, } \\
\text { preserving } \\
\text { water quality, } \\
\text { insectary } \\
\text { shrub plantings, } \\
\text { grassed } \\
\text { roadways, } \\
\text { owl boxes }\end{array}$ \\
\hline 1999 & $\begin{array}{l}\text { BIFS } \\
\text { in rice }\end{array}$ & $\begin{array}{l}\text { Butte } \\
\text { Sutter }\end{array}$ & 8 & 750 & 15,000 & 480,000 & 3.1 & $\begin{array}{l}\text { Straw incorporation, } \\
\text { water management } \\
\text { for weed control, } \\
\text { drill seeding. } \\
\text { winter cover crops }\end{array}$ & $\begin{array}{l}\text { Herbicides, } \\
\text { synthetic } \\
\text { nitrogen } \\
\text { fertilizers }\end{array}$ & $\begin{array}{l}\text { Cover crops, } \\
\text { straw incorporation, } \\
\text { wetland habitat } \\
\text { provided by } \\
\text { winter flooding }\end{array}$ \\
\hline 1999 & $\begin{array}{l}\text { Biologically } \\
\text { Integrated } \\
\text { Citrus } \\
\text { Orchard } \\
\text { Management }\end{array}$ & Fresno & 8 & 155 & 6,360 & $\begin{array}{c}201,811 \\
\text { (navels \& } \\
\text { valencias) }\end{array}$ & 3.2 & $\begin{array}{l}\text { Monitoring and } \\
\text { action thresholds, } \\
\text { cultural, biological, } \\
\text { less-toxic controls, } \\
\text { cover crops, } \\
\text { water management }\end{array}$ & $\begin{array}{l}\text { Broad-spectrum } \\
\text { insecticides } \\
\& \text { herbicides }\end{array}$ & $\begin{array}{l}\text { Cover crops, } \\
\text { preserving } \\
\text { water quality }\end{array}$ \\
\hline 1999 & $\begin{array}{l}\text { Biological } \\
\text { Agriculture } \\
\text { Systems in } \\
\text { Strawberries } \\
\text { (BASIS) }\end{array}$ & $\begin{array}{l}\text { Monterey } \\
\text { Santa Cruz }\end{array}$ & 8 & 16.5 & $\begin{array}{r}700 \\
(86 \\
\text { organic) }\end{array}$ & 23,000 & 3.0 & $\begin{array}{l}\text { Enhance \& release } \\
\text { beneficial species, } \\
\text { nonchemical } \\
\text { weed control such as } \\
\text { hot water, mulches, } \\
\text { broccoli incorporation }\end{array}$ & $\begin{array}{l}\text { Methyl bromide, } \\
\text { organophosphate } \\
\text { insecticides, } \\
\text { acaricides }\end{array}$ & $\begin{array}{l}\text { Native insectary } \\
\text { plants, } \\
\text { grasses for } \\
\text { erosion control, } \\
\text { furrow slope } \\
\text { alignment }\end{array}$ \\
\hline 1999 & $\begin{array}{l}\text { Integrating } \\
\text { Forage } \\
\text { Production } \\
\text { w/Dairy Manure } \\
\text { Management/ } \\
\text { San Joaquin } \\
\text { Valley }\end{array}$ & $\begin{array}{c}\text { Tulare } \\
\text { Fresno } \\
\text { San Joaquin } \\
\text { Stanislaus } \\
\text { Merced }\end{array}$ & 11 & 440 1 & 5,500 91 & $\begin{array}{c}\text { Total } \\
\text { dairy acres } \\
\text { not } \\
\text { available: } \\
1.34 \text { million } \\
\text { dairy cattle, } \\
2,308 \text { farms }\end{array}$ & , & $\begin{array}{l}\text { Forage-crop } \\
\text { nutrient budgeting, } \\
\text { fertility monitoring, } \\
\text { precision irrigation, } \\
\text { water distribution } \\
\text { system improvements }\end{array}$ & $\begin{array}{l}\text { NPK fertilizers, } \\
\text { nitrate in surface } \\
\text { and groundwater }\end{array}$ & $\begin{array}{l}\text { Preserving } \\
\text { water quality } \\
\text { with tailwater } \\
\text { return systems, } \\
\text { overseeding old } \\
\text { alfalfa for nutrient } \\
\text { sequestration }\end{array}$ \\
\hline $2000 \ddagger$ & $\begin{array}{l}\text { Integrated } \\
\text { Pome Fruit } \\
\text { Production }\end{array}$ & Contra Costa & 9 & 757 & 1,540 & 37,000 & 4.2 & $\begin{array}{l}\text { Mating disruption, } \\
\text { reduced-risk insecticides, } \\
\text { monitoring, } \\
\text { biological control }\end{array}$ & $\begin{array}{l}\text { In-season } \\
\text { organophosphate } \\
\text { insecticides }\end{array}$ & \\
\hline Totals & & & 238 & $26,866.5$ & 193,553 & $2,708,961$ & 7.1 & & & \\
\hline
\end{tabular}

- California Agricultural Statistics Service. 1999. Acreage reports. www.nass.usda.gov/ca/rpts/acreage/indexac.htm. Accessed Oct 1999.

$\uparrow$ Recent acreage served by BIFS is calculated as acres farmed by BIFS farmers/total bearing acres in the state $x 100$.

$\mp$ Project funding also provided by others, such as DPR, U.S. EPA or private foundations including Pew Charitable Trusts and Charles Stewart Mott Foundation. $\S$ Not currently supported as a demonstration project by SAREP.

I Estimated acreage.

BIOS: Biologically Integrated Orchard Systems

BIFS: Biologically Integrated Farming Systems 


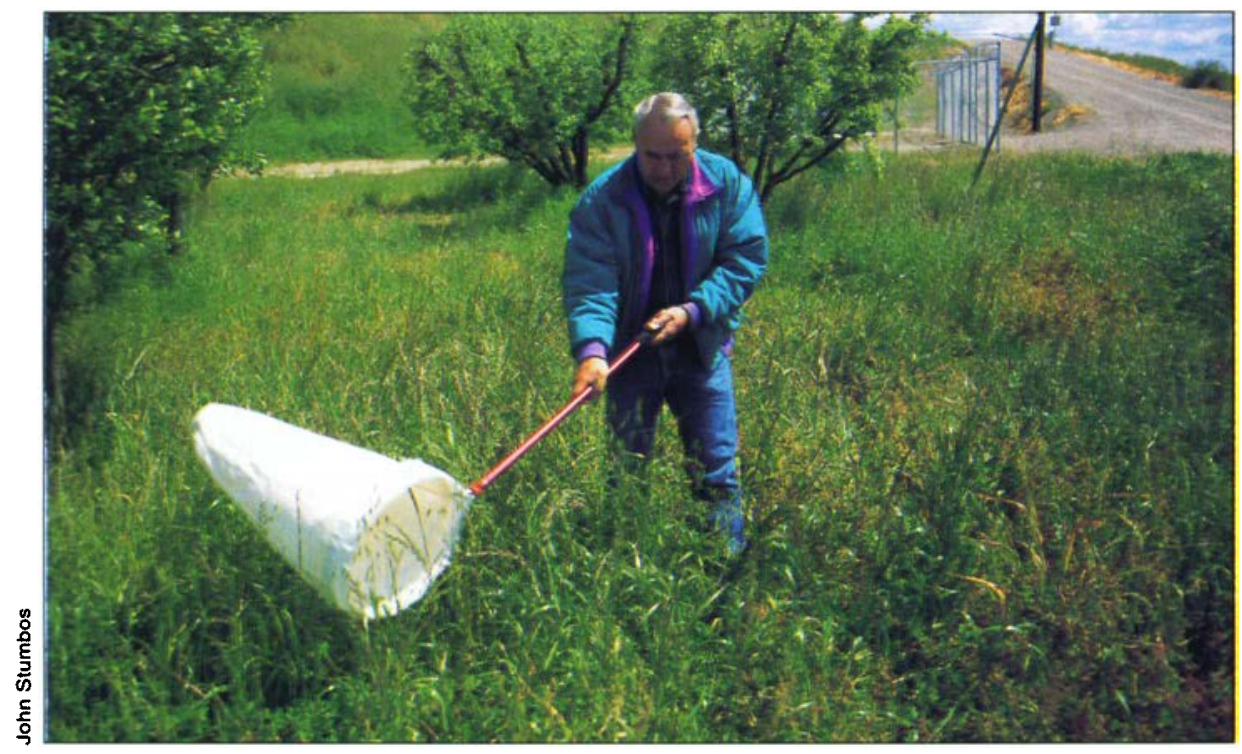

Butte County farm advisor William Olson samples for insects in a prune orchard on the east side of Sacramento Valley. Intensive monitoring, data collection and analysis are increasingly important in agriculture, particularly in "whole-systems" farming. California, the birthplace of integrated pest management (IPM), is a logical setting for the development of BIFS projects. UC Berkeley Professor Robert van den Bosch, right, at work in the mid-1970s, was an IPM pioneer.

acres for 3 years, receives customized farm plans and shares information with other growers (Santer 1995). Each farming system is tailored to take full advantage of grower innovation and university research. To enable greater farmer-to-farmer information-sharing, the demonstration projects utilize nonhierarchical project management teams made up of growers, consultants, university researchers and publicresource-agency personnel (Dlott et al. 1996; Lacy 1996).

Intensive data collection and analysis are becoming increasingly important to all agriculture. Intensive monitoring is integral to BIFS, not only for biological and economic decisionmaking but also for project impact assessment. Whether through automated on-farm collection of weather data, weekly monitoring of pests and beneficial species or monitoring for sitespecific agricultural applications, data collection has reduced and can further limit the use of synthetic pesticides and fertilizers. Such data can also provide evidence for label claims, protect against global trade barriers triggered by food-safety concerns, and inform regulatory agencies about agricultural trends.

\section{Promising results}

All BIFS projects set well-defined chemical-use reduction targets. The re- sults so far have been promising (table 1) (Broome et al. 1997, 1999). For example, many BIOS almond growers and all participating Integrated Prune Farming Practices (IPFP) prune growers have eliminated diazinon applications during the dormant season.

Almonds. BIOS growers in Merced and Stanislaus counties utilized the less-toxic microbial pesticide, Bacillus thuringiensis (Bt), on $20 \%$ to $30 \%$ of their total almond acreage in 1992 and almost $80 \%$ in 1995 , while non-BIOS growers treated only $20 \%$ to $25 \%$ of their orchard area with $\mathrm{Bt}$ (Broome et al. 1997). BIOS almond growers also achieved major reductions in synthetic nitrogen use while simultaneously increasing their reliance on leguminous and grass cover crops.

Wine grapes. The LodiWoodbridge Winegrape Commission has just completed its third year in the BIFS program. By coupling intensive monitoring with economic-injury thresholds for major arthropod pests such as leafhoppers and mites, the region's grape growers have reduced their reliance on pesticides by $50 \%$ for these pests (Broome et al. 1999). They are also beginning to reduce their reliance on simazine.

Resource conservation. Most BIFS projects partner with the U.S. Department of Agriculture's Natural Resources Conservation Service (NRCS)

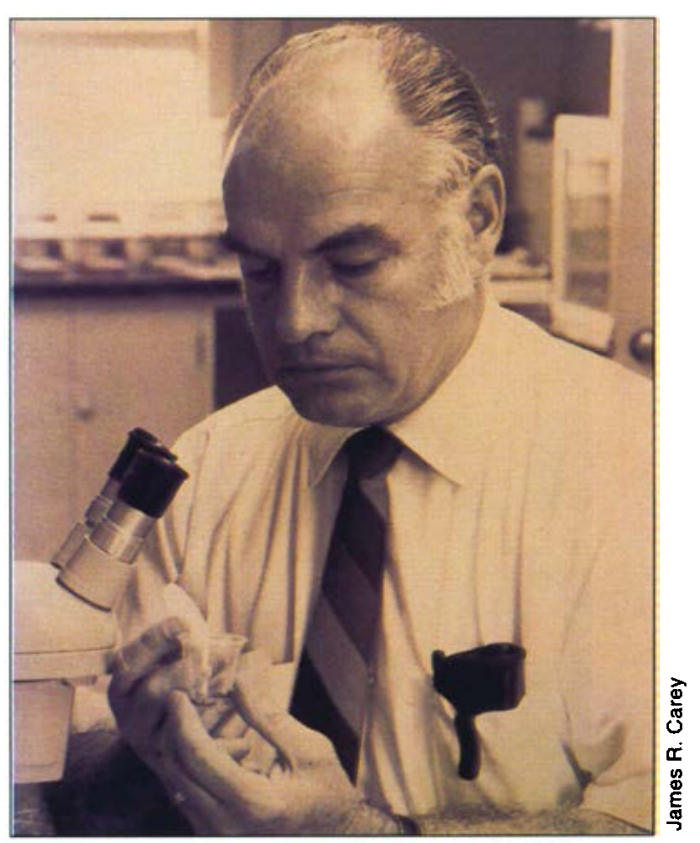

or a local resource conservation district in order to ensure the inclusion of conservation practices in the demonstration system and effectively utilize federal cost shares and conservation subsidies. NRCS is an important partner in the strawberry, citrus, prune, walnut, almond and grape projects (table 1).

Wildlife protection. Some BIFS projects work closely with nonprofit environmental groups such as The $\mathrm{Na}$ ture Conservancy and Point Reyes Bird Conservancy to lessen the impact of agriculture on wildlife. Preliminary migratory-songbird surveys depict increased populations and species diversity in biologically managed prune orchards (King and Geupel 1998).

However, further research is needed in the Sacramento Valley and with other BIFS projects to evaluate whether alternative farming methods benefit wildlife.

The rice BIFS project builds on 5 years of work by the rice industry, UC researchers and Ducks Unlimited to use rice-straw residue management and winter flooding in rice fields. This practice also provides food, water and habitat for millions of waterfowl that migrate along the Pacific Flyway; about 2.5 million birds traveled the Pacific Flyway in the mid-1980s, down from historical highs of 10 million to 12 million (Brouder and Hill 1995). 


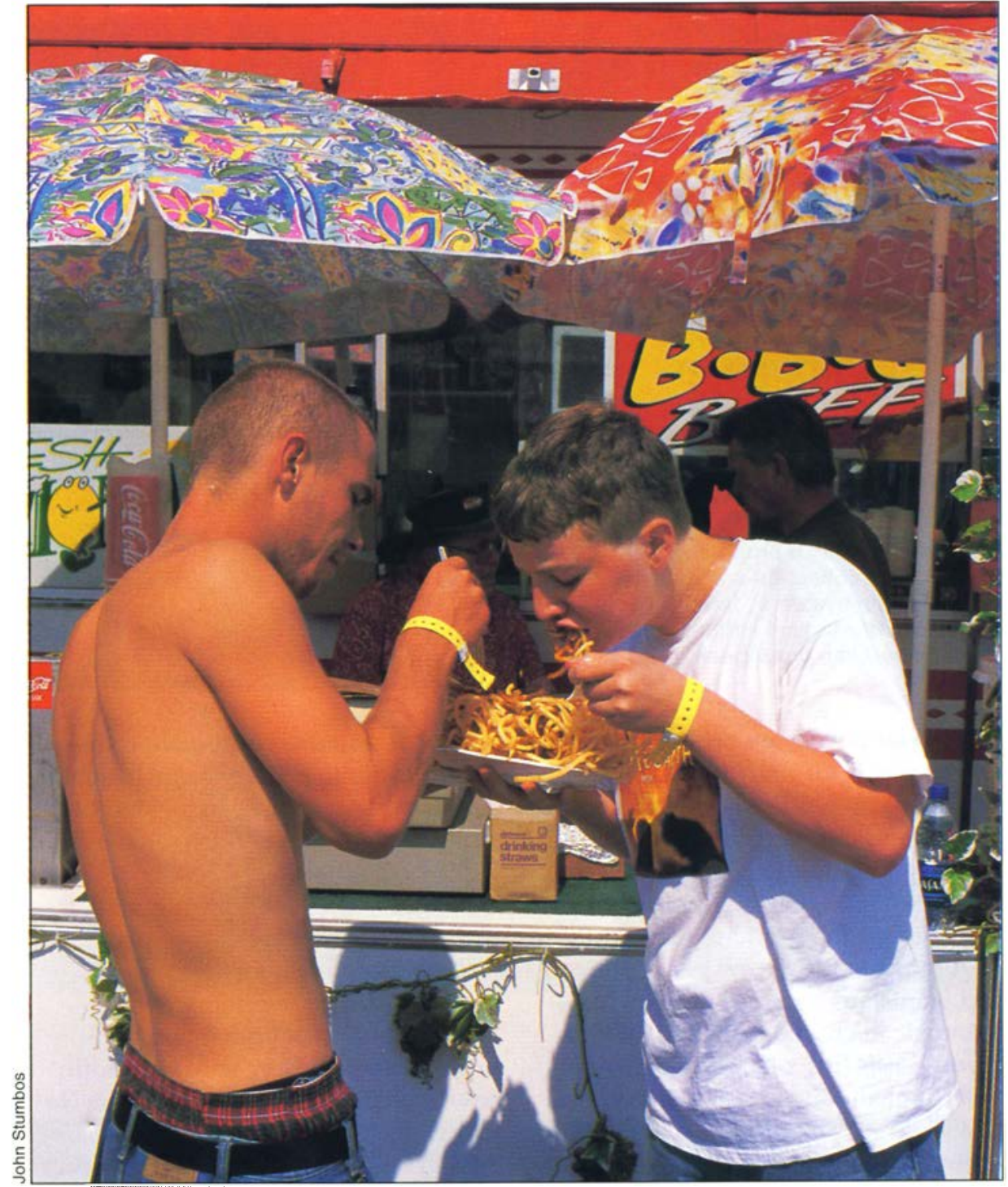

Some major fast-food chains have asked their suppliers not to ship them transgenic potatoes. Consumer interest in organic produce may be partly linked to its prohibition of transgenics.

\section{Historic influences}

Integrated pest management. California is a logical setting for the development of BIFS projects. During the early 1960s, UC launched a major cotton research and education program in the San Joaquin Valley in response to severe pest resurgence and outbreaks of secondary pests. These conditions were traced to indiscriminate applications of broad-spectrum organochlorine and organophosphate insecticides, often used in combination due to pest resistance. The resulting research led to the development of the integrated pest management (IPM) concept.
UC entomologists defined integrated control as the use of chemical controls in a manner least disruptive to biological control (Stern et al. 1959). IPM includes the use of economic thresholds to prevent actual financial losses, pest suppression based on natural regulatory processes, and the use of chemical interventions only when natural processes are deemed ineffective. The historical consensus among researchers and practitioners is that the IPM paradigm has been successful in improving the efficiency of insecticide use, but has had less impact on weed and pathogen control.

While earlier IPM strategies relied on pesticides as the primary manage- ment tool, a new ecologically based pest-management paradigm is emerging (NRC 1996). BIFS pest management redesigns the farming system using biological strategies such as naturally occurring compounds, cultural controls, biological control agents and resistant cultivars, as well as soil amendments and cover crops. The farm system is integrated into the larger landscape with hedgerows and farmscaping.

The organic farming paradigm. Organic agriculture is an ecological farming system that promotes and enhances biodiversity, biological activity and natural cycles. It is based on minimal use of synthetic pesticides and fertilizers and management practices that restore, maintain and enhance ecological harmony (NOSB 1995). A national study by USDA (1996) of organic vegetable farming documents that most growers manage pests through practices such as crop rotation, pest-resistant varieties and adjustment of planting dates.

Organic farms reduce some negative impacts of conventional farming such as soil erosion and leaching of carbon and nitrogen (Reganold et al. 1987; Drinkwater et al. 1998; Siegrist et al. 1998).

One study demonstrated that organic farming could protect wildlife; East Coast organic apple orchards had higher numbers of nontarget insects and supported larger populations of songbirds than orchards where pesticides were used (Fluetsch and Sparling 1994).

Organic agriculture has the added benefit - over BIFS- and IPM-based approaches - of clearly defined standards and a certification process delineated and enforced by the California Department of Food and Agriculture Organic Program and registered third-party certifiers.

\section{Growth of the organic industry}

Organic farming is growing in importance internationally, nationally and in California. European Union consumers spend an estimated $\$ 4.5$ billion on organic products and Japanese consumption ap- 
proaches $\$ 2$ billion per year. In 1997 , the U.S. market for organic products was $\$ 4$ billion, up from $\$ 78$ million in 1980; estimates place the current market at $\$ 6$ billion. In California, average annual organic sales growth was $15 \%$, while acreage growth approximated $10 \%$ per year between 1992 and 1998 with a self-declared farmgate value of over $\$ 150$ million (Klonsky 2000). The actual organic sales figure is assumed to be higher than this total (over $\$ 200$ million) but accurate estimates are not available. A recent USDA survey found that in 1997, California had 96,000 acres in certified organic production (USDA 2000). These data suggest a doubling of California organic acreage from 1992 to 1997, or a greater than $20 \%$ per year increase in acreage.

Consumers of organic products are highly motivated and probable forerunners of future consumer trends. Pressed by the global expansion of organic production and trade, and under provisions of the 1990 Organic Foods Production Act, USDA began rulemaking in 1998 to enact a national, uniform standard. USDA received a record-breaking 275,000 comments on the proposed rule, the vast majority in opposition to the potential inclusion of genetically modified organisms, biosolids and irradiation as organically acceptable practices. The new USDA draft, released for comment in March 2000, eliminates these and many other consumer and grower concerns.

Under provisions of the 1990 California Organic Foods Act, more than 1,500 organic growers registered with county agricultural commissioners in 1997 and that number rose to 1,800 by early 2000 (Ray Green, Organic Program, California Department of Food and Agriculture, personal communication).

The state's major certification organization, California Certified Organic Farmers (CCOF) has over 120,000 total program acres, with more than 95,000 acres certified (Brian McElroy, California Certified Organic Farmers, personal communication).

With new registrations and the activities of several other certification agencies added, we estimate that between $1 \%$ and $2 \%$ of California crop- land is currently in transitional or certified organic production. (California had a total of 89,000 farms on 8.5 million harvested cropland acres in 1998.)

While their percentage is still small, organic farmers serve as mentors in many BIFS projects, sharing their skill and experience with participating growers. Organic farmers serve on project management teams or participate with demonstration acreage in 7 of 10 projects (table 1 ).

Research results and needs. University-directed research on organic production-system performance in California is largely characterized by comparative studies (Hendricks 1995; Gliessman et al. 1996; Swezey et al. 1994; 1999; Temple et al. 1994; Shennan et al. 1991; Drinkwater et al. 1998). These studies point to the need for research to improve yields and pest control, and stabilize income. The studies reveal that the economic incentives available to organic growers include price premiums, lower-input production costs and reduced economic impact from regulations.

\section{Future in focus: \\ The next "green revolution"}

If acreage growth rates of $10 \%$ to $20 \%$ per year continue (from the 1997 USDA base estimate of 96,000 acres of organic production in California), and assuming a reduced cropland base of 7 million acres, as much as $10 \%$ of California's cropland acreage could be organic by 2025 .

This is a conservative linear projection based on present regulations. Technical innovation, market expansion and regulatory pressures could double this estimate - using an exponential growth model - to over $20 \%$ of California's acreage.

BIFS-style partnerships, funded by commodity boards, state agencies and UC, could also expand to cover as much or more acreage than organic during the next 25 years. BIFS projects fall between organic farming and conventional farming. Given the rising costs of regulation and inputs, we predict more acreage will transition to these intermediate or "third-path" farming systems. After only 6 years of activity in California, BIFS growers are estimated to be farming more than 26,000 acres utilizing BIFS farming systems. But these same growers farm a total of 193,553 acres, which they could quickly transition to alternative farming systems.

The commodities currently in BIFS projects covered an estimated 2.7 million total acres in California in 1998, and BIFS demonstration acreage has reached about $1 \%$ of that to date. BIFS growers farm just over $7 \%$ of the total commodity acreage. If we assume the same $10 \%$ linear growth rate for BIFS as for organic, then there could be at least $10 \%$ of California's crop acreage in BIFS by 2025. Technical innovation, eco-label supported market expansion, regulatory pressures, and inclusion of other agencies reduced-risk demonstration programs (like DPR's Pest Management alliance) could greatly increase this estimate - using an exponential growth model - to $46 \%$ of California's acreage. By combining possible increases in organic and BIFSstyle partnership acreage estimates, we predict that from at least $20 \%$ to as much as $60 \%$ of California's farmland will be in such systems by 2025 .

Consumer interest. Cropland acreage increases for organic and BIFS farming will be fueled by consumer concerns about the environmental impacts of farming. The Hartman Group surveyed American consumer attitudes toward food and the environment (The Hartman Group 1996). With roughly $7 \%$ of the population considered "true naturals," who understand what organic means and buy organic products regularly, Hartman identified an additional $23 \%$ of those he surveyed as the "new green mainstream" - consumers who would pay more for products that made claims to being environmentally sound. Exploratory efforts are currently under way by California wine grape, almond and other growers to evaluate "third-way" or "eco" labels as a means of informing consumers about products that incorporate biologically integratèd farming systems. Around the country, numerous eco-labels have been developed such as the Wegmans-Cornell IPM label and The Food Alliance-Approved label in the Pacific Northwest. 


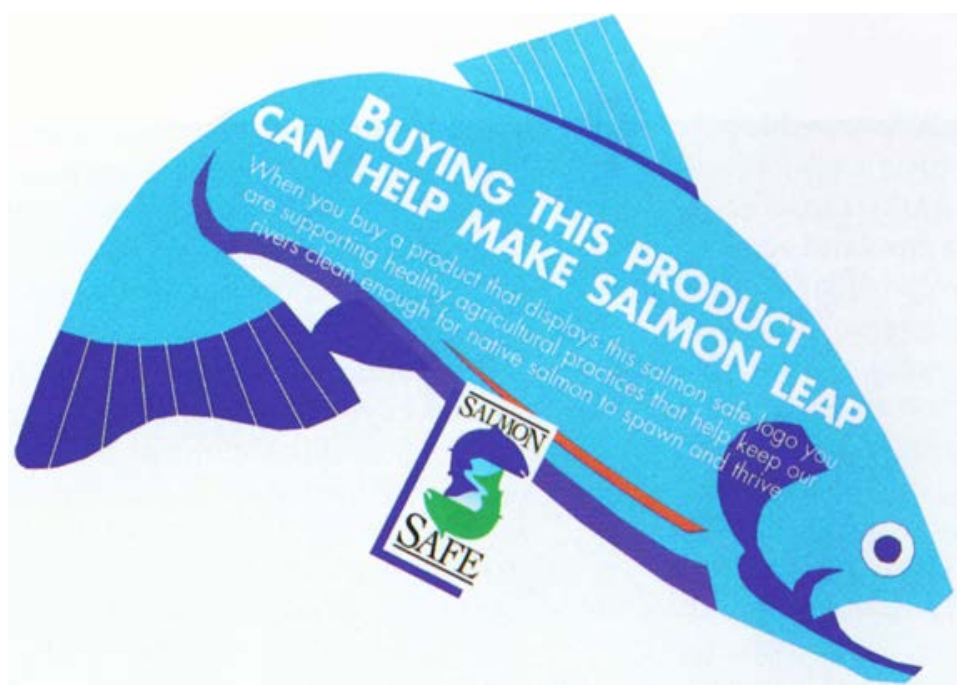

California growers are exploring the use of "eco labels," like these from other parts of the country, to inform consumers about environmentally friendly growing practices.
New partnerships. With or without market incentives, voluntary partnerships for the protection of environmental quality and farm viability will be a future feature of California agriculture. In 1999, a Farm Bureau-sponsored coalition of farmers in Santa Clara, San Mateo, Santa Cruz, San Benito, Monterey and San Luis Obispo counties formed voluntary watershed stewardship groups to fund pilot demonstrations to reduce non-point-source pollution in four watersheds of the Monterey Bay National Marine Sanctuary.

Research funding. Additional research will be essential to support these new farming systems, but research investments have not kept pace with the growth in organic product sales. Several analyses of organic agriculture have noted the lack of increased investment in research to correspond with organic sales growth. For example, one analysis of USDA's
Current Research Information System (CRIS) found that in 1995 only $\$ 1.5$ million in federal funds was devoted to organic farming research projects, representing less than $0.01 \%$ of the agency's research funding that year (Lipson 1997).

The California Sustainable Agriculture Research and Education Act of 1986 stated the goal of "increasing research and education on sustainable agricultural practices ... such as organic methods." Since 1987, UC SAREP has awarded just over $\$ 1.3 \mathrm{mil}-$ lion to 25 research projects deemed directly relevant and immediately applicable to organic farming, about $\$ 100,000$ a year in competitive grants (table 2). This annual investment was less than $0.01 \%$ of California's organic industry sales in 1998.

Transgenic vs. organic crops. Like organic agriculture, the agricultural biotechnology industry has expe-
TABLE 2. Organic relevance of UC SAREP research and education (R\&E), BIFS and methyl bromide (MeBr) grants (1987-1999)

\begin{tabular}{|c|c|c|c|}
\hline $\begin{array}{l}\text { Organic relevance } \\
\text { category }\end{array}$ & $\begin{array}{l}\text { No. of } \\
\text { projects }\end{array}$ & $\begin{array}{l}\text { Amount } \\
\text { funded }\end{array}$ & $\begin{array}{l}\text { Percent of all } \\
\text { funded projects }\end{array}$ \\
\hline & & $\$$ & $\%$ \\
\hline Direct & 25 & $1,340,848$ & 20.2 \\
\hline Indirect & 63 & $4,145,480$ & 62.3 \\
\hline Neutral & 51 & $1,163,168$ & 17.5 \\
\hline Total (R\&E, BIFS, MeBr) & $\overline{139}$ & $\overline{6,649,496}$ & \\
\hline Educational events & 85 & 108,307 & \\
\hline Graduate student awards & 39 & 61,589 & \\
\hline$\overline{\text { TOTAL }}$ & $\overline{263}$ & $6,8 \overline{19,392}$ & \\
\hline
\end{tabular}

Direct $=$ explicit organic experimental context; practices and materials researched compliant with National Organic Standards Board criteria.

Indirect = experimental context not explicitly organic, but practices and materials researched could be directly applied to organic farms.

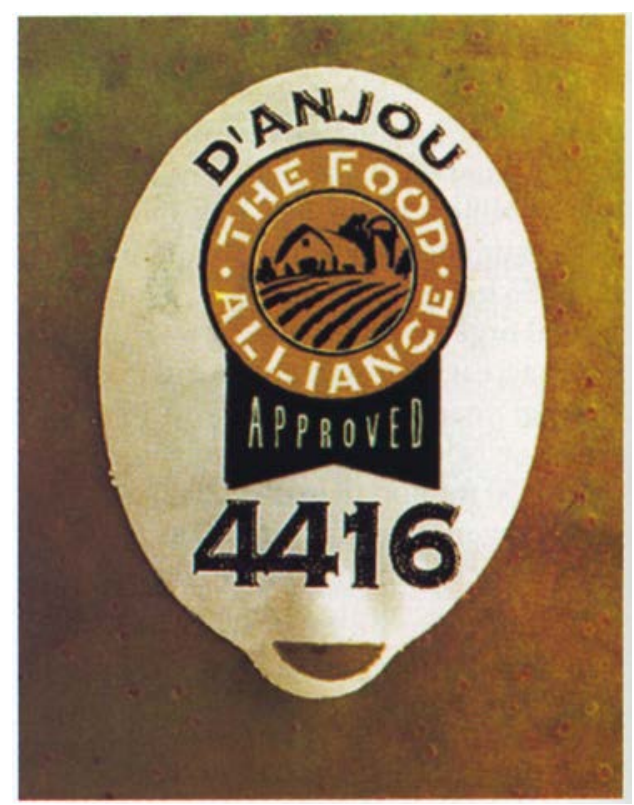

rienced phenomenal growth in recent years. Transgenic crop sales totaled \$236 million in 1996 worldwide and increased six-fold to between $\$ 1.2$ billion and $\$ 1.5$ billion in 1998, with growth projections reaching $\$ 20$ billion by 2010 (James 1997).

Because the food industry has resisted labeling products that contain transgenic ingredients, future growth in the organic industry may be stimulated by the fact that transgenic ingredients will not be permitted by the forthcoming U.S. national organic standards. Indeed, opponents of labeling often argue that consumers who do not want to consume engineered food can simply buy organic.

The BIFS program does not prohibit transgenic technology. However, a central tenet of the BIFS approach is that alternative pest- or soil-management practices must reduce risks to environmental and human health. In addition, consumer acceptance or rejection of biotechnology will certainly be a factor in the decision by BIFS growers to adopt or reject it.

Given all these factors, we believe that a second, greener revolution is on the way (Conway 1998). In this new revolution, shared knowledge of biological processes that determine pest dynamics, soil health and microbial ecology will combine with the demonstrated ability of California growers and agricultural researchers to innovate, thereby maintaining the preeminence of California commodities. Cali- 
fornia producers will expand economic and political alliances with urban consumers through directmarketing, certified organic food and fiber, eco-labeling and educational programs to change the rules of consumer engagement with the food system.

S.L. Swezey is Extension Specialist and Director, UC Sustainable Agriculture Research and Education Program (SAREP), and Adjunct Associate Professor, Environmental Studies, UC Santa Cruz. J.C. Broome is Associate Director, UC SAREP. The authors thank R.L. Bugg and M.T. Stevenson for information on the BIFS program. They acknowledge funding for the BIFS program from U.S. EPA and the California Department of Pesticide Regulation.

\section{References}

Abelson PH, Hines PJ. 1999. The plant revolution. Science 285:367-8.

Barham E. 1997. What's in a name?: Ecolabeling in the global food system. www.pmac.net/bbarham.htm. Accessed Oct 1999.

Bradshaw TK, Muller B. 1998. Impacts of rapid urban growth on farmland conversion: Application of new regional land-use policy models and geographic information systems. Rural Soc. 63(1):1-25.

Broome JC, Bugg RL, Denton D, et al 1999. Promoting environmental health through biologically integrated farming systems. Poster at International Congress on Ecosystem Health. Sacramento, CA. Report \#24. UC Genetic Resources Conservation Program.

Broome JC, Settle WH, Bugg RL, et al. 1997. Biologically integrated farming systems: approaches to voluntary reduction of agricultural chemical use. Proceedings of the Society of Toxicologists and Chemists annual meeting. Poster. San Francisco www.setac.org/ pubsam.html.

Brouder SM, Hill JE. 1995. Winter flooding of ricelands provides waterfowl habitat. Cal $\mathrm{Ag} \mathrm{49(6):58-64.}$

Burow KR, Shelton JL, Dubrovsky NM. US Geological Survey. 1998. Occurrence of nitrate and pesticides in groundwater beneath three agricultural land-use settings in the eastern San Joaquin Valley, California, 1993-1995. USGS Water-Resources Investigations Report 97-4284. p 51.

CALFED Bay-Delta Program. 1999. http:// calfed.ca.gov. Accessed Oct 1999.

Clark WAV. 2000. Immigration, high fertility fuel state's population growth. Cal Ag 54(1):11-8.

Conway G. 1998. The Doubly Green Revolution: Food for All in the 21st Century.
Ithaca, NY: Cornell University Press. 335 p.

Dlott J, Nelson T, Bugg RL, et al. 1996. California USA: Merced County BIOS Project. In: Thrupp LA (ed.). New Partnerships for Sustainable Agriculture. Washington, DC: World Resources Institute. p 115-26.

[DPR] California Department of Pesticide Regulation. 1996. Sampling for pesticide residues in California well water, 1996 update. Well Inventory Database. EH 96-06. Sacramento, CA.

Drinkwater LE, Wagoner $P$, Sarrantonio M. 1998. Legume-based cropping systems have reduced carbon and nitrogen losses. Nature 396:262-4.

Dubrovsky NM, Kratzer CR, Brown LR, et al. 1998. Water Quality in the San Joaquin Tulare Basins, California, 1992-95. Denver, CO: US Geological Survey Circular \#1159. p 38 .

Fluetsch KM, Sparling DW. 1994. Avian nesting success and diversity in conventionally and organically managed apple orchards. Env Tox \& Chem 13:1651-9

Folorunso OA, Rolston DE, Prichard T, Louie DT. 1992. Cover crops lower soil surface strength, may improve soil permeability. Cal Ag 46(6):26-7.

Gliessman SR, Werner M, Swezey SL, et al. 1996. Conversion to organic strawberry management changes ecological processes. Cal Ag 50(1):24-31.

Hartman Group, The. 1996. Food and the Environment: A Consumer's Perspective. Bellevue, WA. The Hartman Group. 60 p.

Hendricks LC. 1995. Almond growers reduce pesticide use in Merced County field trials. Cal Ag 49(1):5-10.

Hunt JW, Anderson BS, Phillips BM, et al. 1999. Patterns of aquatic toxicity in an agriculturally dominated coastal watershed in California. Ag Econ \& Envir 75:75-91.

Ingels CA, Bugg RL, McGourty GT, Christensen LP (eds.). 1998. Cover Cropping in Vineyards: A Grower's Handbook. Oakland, CA: UC DANR Publication \#3338. 162 p.

James C. 1997. Global Status of Transgenic Crops in 1997. International Service for the Acquisition of Agri-biotech Application (ISAAA) Brief \#5. www.isaaa.org. Accessed Oct 1999.

King A, Geupel GR. 1998. Songbird Response to Biological Prune Systems Protocol at Shasta View Farms: Progress Report of the 1997 Field Season to The Nature Conservancy. $25 \mathrm{p}$.

Klienfelder Inc. 1993. Elkhorn Slough 205(j) Uplands Water Quality Management Plan. Prepared for Association of Monterey Bay Area Governments. $49 \mathrm{p}$.

Klonsky K. 2000. A Picture of California's Organic Agriculture. UC Davis Department of Agricultural and Resource Economics. 2 p.

Lacy WB. 1996. Research, extension, and user partnerships: models for collaboration and strategies for change. Ag \& Human Values 13(2):33-41.

Lipson M. 1997. Searching for the O-word: Analyzing the USDA Current Research Information System for Pertinence to Organic Farming. Organic Farming Research Foundation. Santa Cruz, CA. 83 p.
Medvitz AG, Sokolow AD. 1995. Population growth threatens agriculture, open space. Cal Ag 49(6):11-7.

Montgomery Watson Consultants. 1993.

Basin Management Plan. Pajaro Valley Water Management Agency. $165 \mathrm{p}$.

Morse et al. 1997. A Survey of Dairy Manure Management Practices in California. $J$ Dairy Science 80:1841-5.

[NOSB] National Organic Standards Board. 1995. Definition of organic. Drafted and passed at April 1995 meeting in Orlando, FL. www.ota.com/. Accessed Oct 1999.

[NRC] National Research Council. 1996. Ecologically Based Pest Management: New Solutions for a New Century. Washington,

DC: National Academy Press. p 144.

NRC. 1993. Soil and Water Quality: An Agenda for Agriculture. Washington, DC: National Academy Press. p 493.

Prichard TL, Sills WM, Asai WK, et al. 1989. Orchard water use and soil characteristics. Cal Ag 43(4):23-5.

Reaganold J, Elliot P, Unger YL. 1987. Long-term effects of organic and conventional farming on soil erosion. Nature 330:370-2.

Santer L (ed.). 1995. BIOS for Almonds: A Practical Guide to Biologically Integrated Orchard Systems Management. Davis/Modesto, CA: Community Alliance with Family Farmers Foundation and Almond Board of Calif. p 104. Shennan C, Drinkwater LE, Van Bruggen AHC et al. 1991. Comparative study of organic and conventional tomato production systems: An approach to on-farm systems studies. In Rice B, Madden JP (eds.). Sustainable Agriculture Research and Education in the Field. NRC, National Academy Press, Washington DC p 109-32.

Siegrist S, Schuab D, Pfiffner L, et al. 1998. Does organic agriculture reduce soil erodibility? The results of a long-term field study on loess in Switzerland. Ag Econ \& Envir 69:253-64.

Stern VM, Smith RF, van den Bosch R, Hagen KS. 1959. The integrated control concept. Hilgardia 29:81-101.

Swezey SL, Goldman P, Jergens R, Vargas R. 1999. Preliminary studies show yield and quality potential of organic cotton. Cal Ag 53(3):9-16.

Swezey SL, Werner M, Buchanan M, et al. 1994. Granny Smith conversions to organic show preliminary success. Cal Ag 48(6):3644.

[SWRCB] State Water Resources Control Board. 1999. California 305(b) Report on Water Quality. Sacramento, CA. 242 p.

Temple SR, Somasco OA, Kirk M, Friedman D. 1994. Conventional, low-input and organic farming systems compared. Cal Ag 48(5):14-9.

[USDA] US Department of Agriculture. 2000. U.S. Organic Agriculture. Economic Research Service Issues Center. Washington, DC. www.econ.ag.gov/whatsnew/issues/ organic/.

USDA. 1996. Organic vegetable growers surveyed in 1994. Economic Research Service, Natural Resources and Environment Division. Washington, DC. 